\title{
Assessing Proposals for a Transatlantic Free Trade Area
}

\author{
Rolf J. Langhammer, Daniel Piazolo and Horst Siebert \\ Kiel Institute for World Economics
}

In regelmäßigen Abständen erscheinen Initiativen zum Abbau noch bestehender Beschränkungen im transatlantischen Handel oder zur Harmonisierung handelsbeeinträchtigender nationaler Politiken in der EU oder den USA auf der politischen Agenda. In der letzten Dekade gab es auch bedeutende Fortschritte in der transatlantischen Kooperation, die sich auf Einzelaspekte bezogen. Um eine weitere Liberalisierung voranzutreiben, machte der amtierende Präsident des Europäischen Rates im Februar 2002 einen neuen Vorschlag, die Vorteile einer transatlantischen Freihandelszone (TAFTA) in einer Studie zu untersuchen. Dieser Beitrag analysiert neuere Entwicklungen in den transatlantischen Wirtschaftsbeziehungen, diskutiert Änderungen in den Ansätzen, zu einem transatlantischen Regionalismus zu kommen, und präsentiert Schätzungen der ökonomischen Effekte einer transatlantischen Liberalisierung. Angesichts der geringen zu erwartenden Vorteile dieser Freihandelszone und der mit ihr verbundenen Kosten für multilaterale Verhandlungen werden Alternativen zu TAFTA diskutiert. Dabei wird einem multilateralen Ansatz der Vorzug gegeben, der von einer Art offenem Regionalismus begleitet werden könnte.

Keywords: $\quad$ Freihandelszone, EU-Staaten, Vereinigte Staaten JEL Classification: F02, F13, F42

Institutionalizing economic relations between the EU and the US has been on the political agenda for many years. In recent years, however, there has been a shift from the traditional trade policy focus to issues of securing market access and harmonizing trade-related domestic policies. In February 2002, for instance, the EU commissioner for transportation, Loyola de Palacio, proposed the creation of a transatlantic air space. In November 2001, the German noble laureate in economics, Reinhard Selten, stated that a common transatlantic currency is "by all means possible" ${ }^{\text {. Large }}$ transatlantic mergers as between Daimler Benz and Chrysler underline that transatlantic cooperation in competition policies is an issue of growing importance.

The academic discussion on institutionalization of transatlantic economic relations has centred primarily on the merits of a free trade area between the EU and the US (cf. SIEBERT et al. 1996; WoLfE 1996; DONGES ET AL.

1 R. Selten stated «Es ist durchaus im Bereich des Möglichen, dass es zu einer transatlantischen Währungsreform kommt, der Euro irgendwann mit dem Dollar zusammengeführt wird» (cf. Der Handel, 1.11.2001). 
1997; LÜBCKE and PIAZOLO 1998; HindLEY 1999; SCHOTT and OEGG 2001; SIEBERT 2002). This article resumes the traditional debate on the effects of such an area and departs from recent policy initiatives in transatlantic relations during the nineties (Section 1). These initiatives have been accompanied by important changes in EU and US policies towards bilateral and regional trade relations. These changes will be introduced in Section 2. Section 3 discusses the potential benefits which may arise from TAFTA (Transatlantic Free Trade Area) while Section 4 addresses its costs both internally as well as externally for third parties. Section 5 stylizes alternatives to a rigid institutionalized FTA (Free Trade Area) without forgoing its benefits. Section 6 concludes on the results.

\section{Transatlantic Economic Cooperation since the Madrid Summit}

As a result of the 1990 Transatlantic Declaration, EU-US economic summits were introduced to give bilateral relations a new momentum. Each of these summits addressed a special aspect of cooperation. At the EUUS summit of December 1995 in Madrid, the EU and the US formally approved the New Transatlantic Agenda (NTA) and a Joint EU-US Action Plan for implementation. Apart from economic and trade issues, the NTA included a wide range of commitments to cooperate in areas such as foreign and security policy, international crime, drug trafficking preventions, migration, environment and health. With the NTA, the EU and the US tried to establish an institutionalized forum for transatlantic cooperation and to increase the scope for joint action without moving toward institutionalized regional integration.

At the EU-US Summit of May 1997 in the Hague, the Agreement on Customs Cooperation and Mutual Assistance in Customs Matters was signed and in December 1997 the Science and Technology Agreement was endorsed, which extends and strengthens the conduct of co-operative activities between EU scientific institutions and a range of US government research agencies.

One year later in May 1998 in London, the Transatlantic Economic Partnership (TEP) was created, which seeks to improve the economic relationship between the EU and the US as well as to create an open and more accessible world trading system. In the same year, the European Commission and the US Administration accepted the TEP Action Plan that identified areas for common actions of bilateral as well as multilateral con- 
cerns. Apart from a comprehensive TEP Steering Group, specialized working groups focusing on specific issues of the TEP Action Plan (like the TEP Working Groups on Technical Barriers to Trade, Biotechnology, or Food Safety) were set up. The TEP Steering Group provides also the forum for the recommendations of the transatlantic dialogues, i.e. the Transatlantic Business Dialogue, the Transatlantic Environment Dialogue, the Transatlantic Consumers Dialogue, the Transatlantic Labor Dialogue, the Legislators' Business Dialogue and the Transatlantic Development Dialogue.

In June 1998, also the EU-US Agreement on the application of positive comity principles in the enforcement of competition laws was signed, and in December 1998 the EU-US Agreement on Mutual Recognition became effective covering specific goods areas like pharmaceuticals, medical devices, telecom equipment, electromagnetic compatibility, electric safety and recreational craft.

At the EU-US Summit of June 1999 in Bonn, both sides committed themselves to a "full and equal partnership" in economic, political and security affairs, which was seen as further advancement since the NTA document. The EU-US Veterinary Equivalence Agreement was signed in July 1999 and aims at facilitating trade in live animals and animal products.

At the EU-US Summit of May 2000 in Lisbon, the Consultative Forum on Biotechnology was established to improve the communication and understanding on the various concerns involved in biotechnology. Furthermore, progress on the so called "Safe Harbor Principles" for the adequate protection of personal data transfers was made.

At the EU-US Summit of June 2001 in Göteborg, the shared commitment for a new round of multilateral trade negotiations at the WTO Ministerial Meeting in Doha was emphasized as well as the need to promote the digital economy and to make its benefits available to all citizens.

In February 2002, the Spanish government holding the EU presidency at that time, initiated a call for a study of the benefits of lower transatlantic trade barriers.

Such regularity in bilateral cooperation could suggest a détente in transatlantic trade policy disputes which in the past rattled the multilateral trading system again and again. However, this has not been the case. 
Disputes on banana trade, trade in hormone-treated beef and genetically modified organisms, tax privileges of Foreign Sales Corporations, and on safe-guard tariffs imposed against US steel imports, to name only few of them, have figured prominently in the WTO dispute settlement mechanism and sometimes remained unresolved throughout the entire procedure. Both actors report permanently on barriers to the partner country's market $^{2}$ and exchange views how to settle disputes bilaterally as well as multilaterally. Interestingly, many of these disputes do not cover border measures but trade-related domestic policies. Hence, they would not necessarily vanish if an "old age" free trade area (FTA) would be established. Instead, to be meaningful, a "new age" FTA would have to include harmonization of trade-related domestic policies ${ }^{3}$.

\section{Policy Shifts in EU and US Regionalism}

In the nineties, both parties have changed their policies toward regionalism significantly.

First, the EU announced to convert non-reciprocal preferential agreements into reciprocal FTAs in order to comply with WTO commitments of tighter discipline enforced against invoking GATT Art. XXIV. Regionally, such conversion refers to bilateral agreements with the Mediterranean countries and with the so-called Lomé group of African, Caribbean and Pacific (ACP) countries. Furthermore, as in Central Europe where in addition to the Europe Agreements with the EU a FTA was formed between the accession candidates under EU initiative, the EU encourages the formation of regional groupings among Mediterranean countries on the one hand and ACP countries on the other hand. Such groupings will erode the hub-and-spoke character of former bilateral agreements which gave the EU as the hub privileged access to all "spokes" while denying the spokes privileged access to each other markets.

Second, the EU has negotiated and concluded FTAs with countries outside Europe such as the Latin American integration scheme Mercosur and with Mexico. Given that these countries will never be eligible for EU membership, the EU expands reciprocal agreements beyond the Euro-

2 In July 2001, the EU Commission issued the $17^{\text {th }}$ annual report on US barriers to trade and investment and the US Trade Representative in his annual report lists EU barriers, respectively.

3 See for such "new age" agreement the recent case of a bilateral FTA between Japan and Singapore (HERTEL et al., 2001). 
pean region where such agreements could be understood and legitimized as pre-accession "training" stages. Instead, agreements with Latin American countries can be explained by "level playing field" motives, i.e. to match the US initiatives "to go regional" with these countries. It is evident that the EU move towards regional and bilateral agreements with Latin American countries erodes US preference margins and thus faces concerns in the US. However, it is argued that EU FTAs with Latin American countries strengthen the reform momentun in these countries and their international competitiveness and thus will also be beneficial for US traders and investors (SCHOTT and OEGG 2001).

The US policy shifts have been even more profound. Since the foundation of NAFTA, the US has increasingly deviated from its traditional post-war multilateral course and promoted regional agreements. The year 2001 was a watershed in this respect when the US President in his annual trade policy agenda declared EU regionalism as a benchmark to be followed by the US. In the same year, the hemispheric endeavour of a Free Trade Agreement of the Americas (FTAA) linking all Latin and North American countries and hence avoiding the hub-and-spoke-syndrome was launched under US initiative. Agreements with Jordan and Asian countries are under way while the US support for the multilateral system remains ambiguous as indicated by the difficulties in achieving congressional endorsement of a WTO negotiation mandate for the US President.

The move toward regionalism in US policies may have received indirect support by the apparent stagnation of a "third way" between regionalism and multilateralism which was promoted by the US, i.e., the so-called "open regionalism" in the Asia-Pacific Economic Cooperation APEC. APEC which comprises all neighbouring countries of the Pacific rim aims at a free trade area in 2020 at the latest and is a regionally concerted nonbinding peer-driven approach toward free trade within an area which except for the EU would include all major trading partners in the world (LANGHAMMER 1999). As concessions are non-binding and open to all non-APEC countries which adhere to the APEC approach, APEC is similar to conditional MFN treatment. Consequently, APEC is not notified under GATT Art. XXIV.

To sum up, the US and EU have not only converged in terms of the general thrust of their trade policies, both now "going" more regional. They have also used trade policies to penetrate in each others economic backyard, the EU in Latin America and the US in the Mashreq area. Such 
expansion may open new areas of conflict but may also extend overlapping interests beyond the direct transatlantic trade and capital flows. The banana conflict between two basically non-banana producing areas indicates that both trade and investment interests of the two actors go far beyond their own territories. Via globalization of capital markets, almost each third country issue in trade policies automatically involves vested interests of the EU or US private sector. This has to be taken into consideration when focusing the negotiation issues between the EU and the US on the narrow aspect of direct bilateral interactions.

\section{Stylised effects of TAFTA}

Minimising discrimination against third countries at a given level of efficiency gains from forming a FTA is a yardstick which regional arrangements have to satisfy when compared to multilateral arrangements. The Vinerian customs union theory has provided the workhorse to specify the criteria when referring to trade creation as welfare enhancing effects of integration deepening and trade diversion as welfare decreasing effects of discrimination against third countries.

\subsection{Trade creation exceeding trade diversion?}

As a rule of thumb, the welfare-enhancing effect of efficiency gains inside the union (often referred to as a result of trade creation) is expected to exceed welfare-decreasing discrimination outside the union (referred to as trade diversion)

- the larger the initial share of the member countries in world trade

- and the larger the initial share of intra-regional trade in the total trade of the member countries.

These two criteria can be applied to TAFTA.

The EU and the US are the leading individual players of world trade closely followed by Japan. However, this ranking does not indicate an overwhelmingly dominant position in world trade. In 1999, the two actors accounted for 34 per cent of world total exports (including commodities) and 39 per cent of world manufactured exports (Table 1). Hence, more than 60 per cent of world trade (excluding intra-EU trade) cannot be attributed to them but to trading partners basically in Asia and other countries of the Western hemisphere. Whether TAFTA meets the first criterion 
is particularly questionable due to the observation that the trend since 1980 has been either stagnating (total trade) or declining (manufactures). This is most visible in manufactured exports where trade policies are especially relevant because of higher trade barriers than for commodities. While the share of the US in world manufactured exports remained more or less constant, that of the EU declined visibly due to both slower economic growth and inward orientation. With more dynamic trading partners outside TAFTA than inside, the risk of sizable discrimination effects cannot be ignored.

Table 1 EU and U.S. Shares in World Exports', 1980-1999 (percentage)

\begin{tabular}{llccc} 
& \multicolumn{2}{c}{ Total trade } & \multicolumn{2}{c}{ Manufactures } \\
& $E U$ & United States & $E U$ & United States \\
\hline 1980 & 18.9 & 13.4 & 29.3 & 17.8 \\
1990 & 20.6 & 14.5 & 24.8 & 16.1 \\
1996 & 20.1 & 14.7 & 23.3 & 16.1 \\
1997 & 19.6 & 15.5 & 22.7 & 17.3 \\
1998 & 20.3 & 15.5 & 23.0 & 17.3 \\
1999 & 19.3 & 15.2 & 21.7 & 17.1 \\
\hline
\end{tabular}

a excluding intra-EU trade.

Source: UN, Monthly Bulletin of Statistics, February, May issues, monthly.

As concerns the second criterion, the magnitude of intra-area trade, similar conclusions can be drawn as to the first one (Table 2). Both the US and the EU largely trade with other countries and again the overall trend in intra-"TAFTA"-trade has been declining, especially in manufactures, with the exception of the importance of the US market for EU manufactures.

Table 2 Intra-TAFTA Trade Shares ${ }^{\mathrm{a}}$, 1980-1999 (percentage)

\section{U.S. Share in}

Extra-EU Exports Extra-EU Imports

Total Manufac- Total Manufactures tures

\begin{tabular}{lllllllll}
\hline 1980 & 12.7 & 13.0 & 16.1 & 28.4 & 26.7 & 25.4 & 16.1 & 26.5 \\
1990 & 18.1 & 18.8 & 17.5 & 22.2 & 24.9 & 26.1 & 20.1 & 22.5 \\
1996 & 18.0 & 19.0 & 18.1 & 21.6 & 20.6 & 21.0 & 18.1 & 20.2 \\
1997 & 19.4 & 20.4 & 19.0 & 23.3 & 20.6 & 21.0 & 18.5 & 20.7 \\
1998 & 21.1 & 22.5 & 19.3 & 23.0 & 22.2 & 22.6 & 19.5 & 21.5 \\
1999 & 23.0 & 24.4 & 19.1 & 22.7 & 22.2 & 23.2 & 18.9 & 20.8 \\
\hline
\end{tabular}

aexcluding intra-EU trade.

\section{EU Share in}

U.S. Exports

U.S. Imports

Total Manufac- Total Manufac-

tures

tures

Source: UN, Monthly Bulletin of Statistics, February, May issues, monthly. 
Merging the two criteria yields that in 1999 only about 9 per cent of world manufactured exports was due to US exports to the EU and EU exports to the US (after 8 per cent in 1980). While this may signal a still untapped potential for trade expansion between the two areas, it mainly suggests that trade diversion effects of bilateral trade liberalization to the disadvantage of more dynamic trading partners outside TAFTA can be substantial.

\subsection{Quid pro quo investment as a shelter against a fortress TAFTA?}

Unlike in trade, EU-US foreign direct investment flows are substantial in both directions. The EU as well as the US are for one another the most important hosts for investment activity partly because the Asian markets (including Japan) have only recently started to liberalize FDI inflows. By end-1999, 46 per cent of the US FDI stock was located in the EU-15 compared to 43 per cent in 1990 (see Figure 1). In manufactures, almost half of total US FDI was located in the EU by end of the last decade. A particulary attractive sector for US FDI in Europe was the service sector after being liberalized in the context of the EU 1992 programme to complete the single market. While in 1980 only 30 per cent of total US FDI in services were in Europe, this figure had risen to almost half some twenty years later.

Reproduced with permission of the copyright owner. Further reproduction prohibited without permission. 
Figure 1: EU Share in U.S. FDI Stock by Sector, 1980-1999 (in per cent)

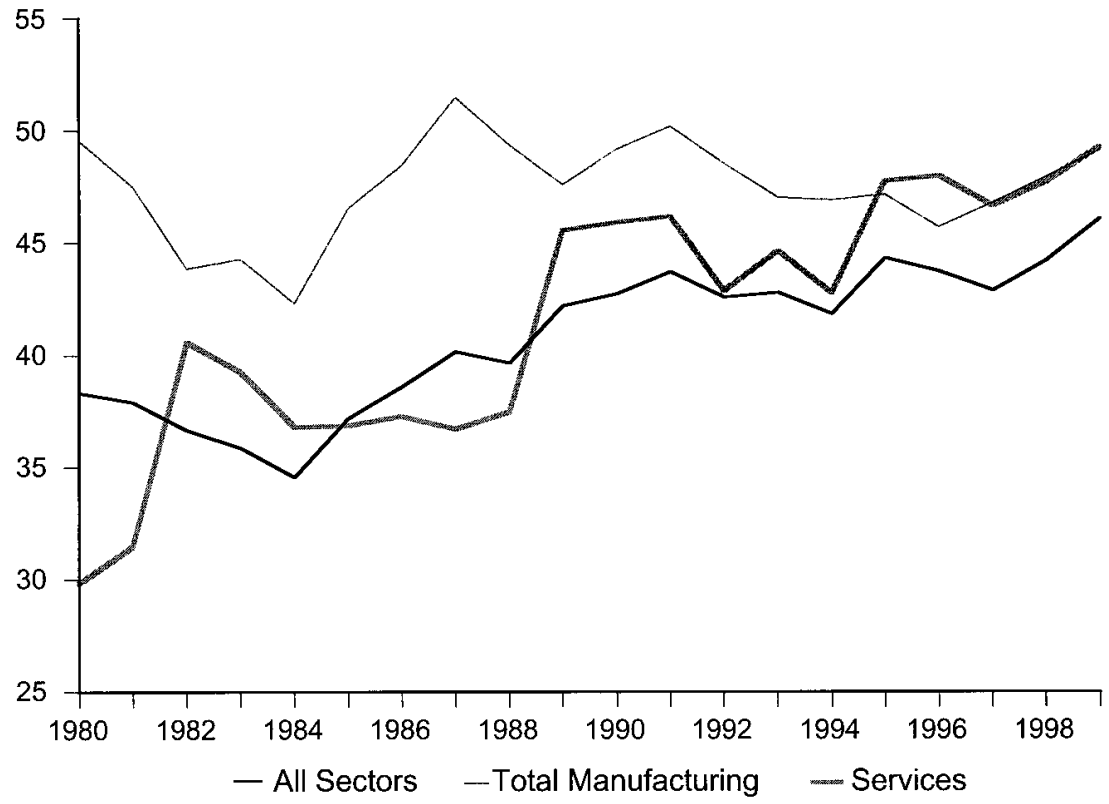

Source: U.S. DePARTMENT OF COMmerce, Survey of Current Business, various issues.

The other direction of investment flows is likewise substantial. In 1998, almost 49 per cent of total extra-EU FDI assets were held in the US. For the period 1992-98, this amounted on average to more than 51 per cent (EUROSTAT 2001, p. 23).

In terms of FDI outward flows, the US has become even more attractive during the nineties. From 1992 to 1999, the share of the US in total extraEU FDI outward flows rose from 39 per cent to 69 per cent with annual average growth rates of almost 60 per cent (see Figure 2). 
Figure 2: US Share in Total Extra-EU-15 FDI Outward Flows, 1992-1999 (in per cent)

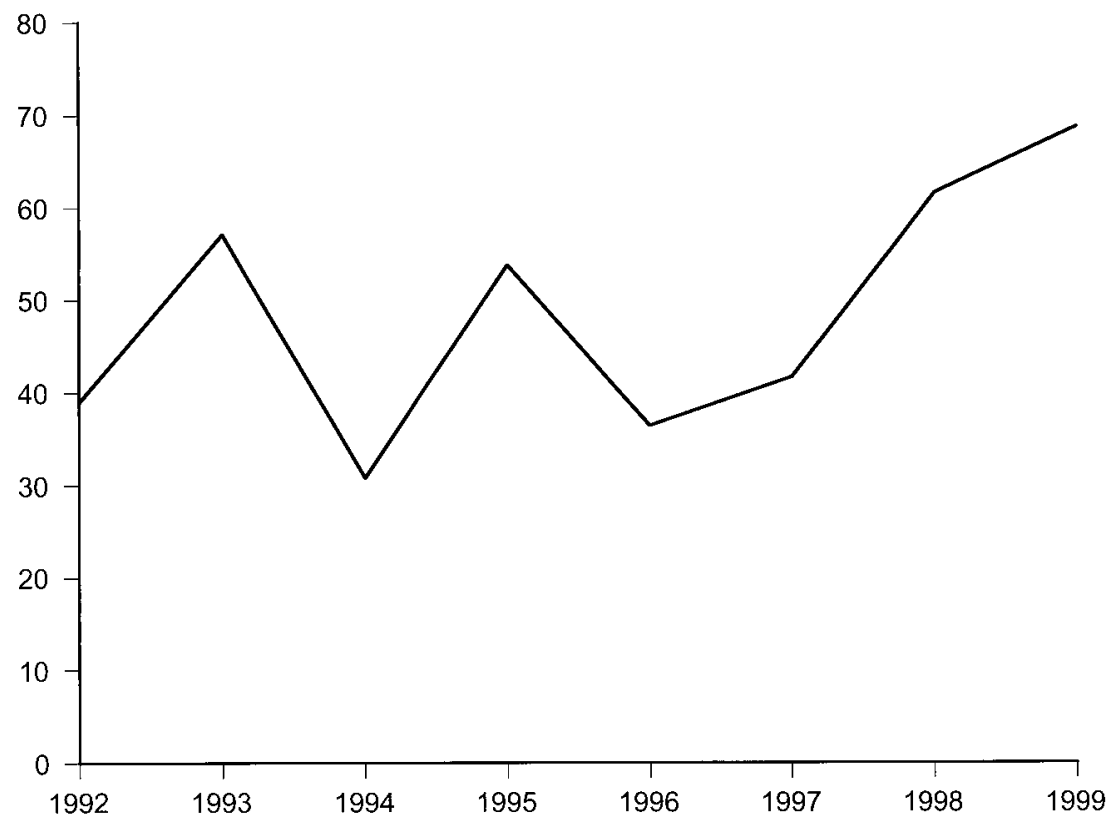

Source: EuRostat (2001).

Overall, the outstanding characteristic of the EU-US economic relations is the mutual inter-linkage through $\mathrm{FDI}^{4}$. Companies from both regions have considerable assets in the other region's market and are therefore strongly inclined to maintain well functioning transatlantic trade links in the absence of TAFTA. In this respect, foreign risk capital can act as quid pro quo investment, i.e. to diffuse protectionist threats by taking influence on the formulation of trade policies in the host country (BHAGWATI, DinOPOULOS and WONG 1992). It seems largely due to the intensity of bilateral investment ties that serious trade policy conflicts in the past could always be finally settled without escalating into a trade war.

The central role of transatlantic FDI can be substantiated at the firm level, too, by consulting the DOME Database On Mergers in Europe. DOME consists of all merger cases between 1990 and the end of 1999 that were examined by the European Commission and therefore provides a good

4 This implies a new channel of interdependence in the business cycle.

Reproduced with permission of the copyright owner. Further reproduction prohibited without permission. 
base to examine transatlantic activites in more detail (DOME 2002; HAMmermann and KLEINERT 2001).

Table 3 gives a detailed classification of all investigated merger cases by the European Commission (column 1) by providing the number of merger cases that involve only EU countries (column 2), EU and Non-EU countries (column 3) or only Non-EU countries (column 4). Furthermore, Table 3 gives the number of transatlantic merger cases (column 5) and their share in total (column 6) and in all the cases involving EU and NonEU countries (column 7). During the period 1990 to 1999, the transatlantic activities accounted on average for 12.8 percent of all merger inquiries and for 58.2 percent of the inquires involving EU and Non-EU countries. This underlines that for extra-EU activities of EU companies, the US is by far the most decisive country. From 1990 (with 33.3 percent of all cases involving EU and Non-EU countries) to 1999 (with 66.2 percent of all these cases) the US gained considerable importance. Consequently, increasing transatlantic activities of companies lead to further economic and institutional interdependencies of the countries - even without the fixed setting of a TAFTA.

Table 3: Significance of Transatlantic Merger Cases for European Companies

\begin{tabular}{|c|c|c|c|c|c|c|c|}
\hline & 1 & 2 & 3 & 4 & 5 & 6 & 7 \\
\hline \multirow[t]{2}{*}{ Year } & $\begin{array}{l}\text { Overall } \\
\text { number of } \\
\text { merger } \\
\text { cases }\end{array}$ & $\begin{array}{c}\text { Number } \\
\text { of purely } \\
\text { intra-EU } \\
\text { merger } \\
\text { cases }\end{array}$ & $\begin{array}{c}\text { Number of } \\
\text { merger } \\
\text { cases } \\
\text { involving } \\
\text { EU and } \\
\text { non EU } \\
\text { countries }\end{array}$ & $\begin{array}{c}\text { Number of } \\
\text { merger } \\
\text { cases } \\
\text { involving } \\
\text { only } \\
\text { non EU } \\
\text { countries }\end{array}$ & $\begin{array}{c}\text { Number of } \\
\text { transatlantic } \\
\text { merger } \\
\text { cases }\end{array}$ & $\begin{array}{c}\text { Share of } \\
\text { transatlantic } \\
\text { merger } \\
\text { cases } \\
\text { in total }\end{array}$ & $\begin{array}{c}\text { Share of } \\
\text { transatlantic } \\
\text { merger } \\
\text { cases in } \\
\text { all cases } \\
\text { involving } \\
\text { EU and } \\
\text { non EU } \\
\text { countries }\end{array}$ \\
\hline & $I$ & II & III & $I V$ & $V$ & VII & VIIII \\
\hline 1990 & 11 & 5 & 3 & 3 & 1 & 9.1 & 33.3 \\
\hline 1991 & 95 & 63 & 22 & 10 & 13 & 13.7 & 59.1 \\
\hline 1992 & 82 & 62 & 17 & 3 & 10 & 12.2 & 58.8 \\
\hline 1993 & 71 & 51. & 13 & 7 & 7 & 9.9 & 53.9 \\
\hline 1994 & 133 & 101 & 21 & 11. & 13 & 9.8 & 61.9 \\
\hline 1995 & 149 & 95 & 41 & 13 & 16 & 10.7 & 39.0 \\
\hline 1996 & 176 & 125 & 36 & 15 & 22 & 125 & 61.1 \\
\hline 1997 & 236 & 159 & 54 & 23 & 29 & 12.3 & 53.7 \\
\hline 1998 & 295 & 197 & 60 & 38 & 39 & 13.2 & 65.0 \\
\hline 1999 & 278 & 187 & 68 & 33 & 45 & 16.2 & 66.2 \\
\hline Sum & 1526 & 1045 & 335 & 156 & 195 & 12.8 & 58.2 \\
\hline
\end{tabular}

Sources: DOME (2002), HAMMERMANN and KLEINERT (2001), own calculations. 


\subsection{Does imperfect competition wipe out concerns about TAFTA?}

The EU and the US share similarities in their income stage, levels of technology, and in the availability of capital and skilled labour. In a gravity model context, these similarities stand for "mass" and facilitate bilateral trade flows, in contrast to "distance" as the trade-impeding factor. Yet, it is less the volume that matters here but the composition of trade. Similarities in factor endowment and high income levels suggest intra-industry trade based on imperfect competition to be dominant rather than interindustry trade. Intra-industry trade is based on economies of scale as well as variety of preferences on the demand side and allows countries to benefit from larger markets and to consume a greater variety of goods. Under such conditions, the traditional trade creation and trade diversion debate based on perfect competition loses some of its relevance. What could make a high share of intra-industry trade an asset in this context is that it is much less vulnerable to protectionism than inter-industry trade. Political opposition against liberalization is diffused if freeing trade leads to expansion of both exports and imports in the same sector. Opposition against trade concessions on the import side can be contained if liberalization promises to stimulate own exports from this sector, too. Both quid pro quo investment and intra-industry trade can stimulate the formation of a TAFTA but they can also protect transatlantic economic relations against a possible failure of an institutionalized free trade area. Liberalization is furthermore facilitated if the degree of openness between the members of a free trade arrangement is similar. Such openness can be approximated by the contribution of external imports to total domestic supply (apparent consumption). In the US and EU, this contribution was fairly similar during the eighties and early nineties (SIEBERT et al. 1996, p. 60).

\subsection{Are fears about discrimination effects against third countries overrated?}

The concept of "New Regionalism" (ETHIER 1998) defends its positive assessment toward regional or bilateral trade agreements by pointing to the endogeneity of regionalism: It is derived from successful multilateral liberalization since a multilateral dismantling of border barriers is expected to favour trade with closer partners relative to trade with more remote partners anyway. In this realm, trade diversion effects would not play a major role since trade barriers vis-à-vis third countries had already been 
cut multilaterally thus leaving preference margins of intra-area trade at a low level.

The EU and the US seem to meet such preconditions. After the Uruguay Round, their average bound industrial tariffs are among the lowest of all WTO member states, i.e., 4.1 per cent and 3.9 per cent, respectively. All tariff lines are bound and the share of tariff lines with peak tariffs (above 15 per cent) is low as well ( 3.5 per cent and 1.5 per cent, respectively (WTO 2001, Table II.2). Thus, cutting the remaining tariffs completely should neither result in major revenue losses nor be strongly opposed by affected industries. The former is relevant in the US because under US law such losses have to be compensated for by other revenues.

However, average tariffs and the focus on industrial tariffs conceal remnants of highly protected activities. Tariff escalation still exists in both industry and agriculture areas thus discriminating against finished goods industries and particularly against labor-intensive suppliers from the developing world, for instance in apparel items and specific processed food products. And even after the full implementation of the Uruguay Round, the estimates of the simple average MFN tariff rates for agriculture (excluding fish) are 9 per cent for the US and 20 per cent for the EU (FINGER, INGCO and REINCKE 1996, p. 52). Estimates on the share of producer subsidies in producer's gross receipts arrive at rates of almost 50 per cent in the EU and about half of that in the US. They indicate how widely the agricultural sector is still decoupled from market forces. It is very likely that under these conditions TAFTA would concede agriculture the same special status different from that for industrial products as it was conceded in the EEC after 1957.

It is obvious that the dismantling of remaining low average tariffs in bilateral trade parallel to the implementation of the Uruguay Round implies small preference margins compared to MFN treatment. Static trade effects would be small, too. SCHOTT $(1995$, p. 6) estimates that the total elimination of tariffs on bilateral trade would increase US exports to the EU by about 10.8 per cent and EU exports to the US by 6.3 per cent. This would be equivalent to an increase of total US trade of only 2.3 per cent (1993 figures) or 0.2 per cent of US GDP. For the EU, such static effects would be even lower ( 1.1 per cent and 0.1 per cent). Even if one takes into consideration that neither non-tariff barriers nor dynamic effects are taken into account, it is suggestive to argue that intra-TAFTA tariff liberalization confined to merchandise trade is unlikely to have a strong effect on 
changes in national income of the two trading partners. Nor can large trade diverting effects be expected to emerge from tariff dismantling only. Yet, this analysis neglects potential investment-creating effects of TAFTA as well as its incentives for product innovation derived from the strong intra-industry component in bilateral trade.

\section{The Costs of TAFTA}

The preceding section has presented some arguments against the view that founding TAFTA as a traditional free trade area would be a sea change compared to the pre-TAFTA period. Nevertheless, costs both for the partners as well as for the rest of the world should not be ignored. In fact, TAFTA would have a number of important internal and external consequences.

\subsection{The Domestic Dimension of TAFTA}

The basic domestic dimension of TAFTA consists of submitting all sectors and industries to the GATT discipline demanded in GATT Art. XXIV. This article requires to include "substantially all trade" in intra-FTA trade liberalization. It is known that neither in the GATT period nor during the early years of the WTO, this discipline could be enforced. Most FTAs regardless of whether they can be labeled "old" or "new" still exclude "sensitive" sectors, above all agriculture (see LANGHAMMER and WÖBMANN 2002). As a result, unequal treatment of sectors within a FTA distorts allocation decisions, supports costly excess capacities in protected industries and sectors and encourages the emergence of rent-seeking activities beyond national boundaries.

Within TAFTA, agriculture which is protected in both partner areas but considerably more in the EU would be a showcase as can be witnessed by a number of empirical estimates. In his "1994 National Trade Estimate Report on Foreign Trade Barriers", the US Trade Representative claims that the elimination of the entire EU agricultural support system including variable levies, price supports and export subsidies would increase US exports to all EU markets between $\$ 4$ billion and $\$ 5$ billion while decreasing US imports about $\$ 2$ billion (USTR 1994, p. 73). 
How far-reaching the liberalization of agricultural policies in the EU would be in terms of world welfare gains, is suggested by general equilibrium models. They yield that about half of all welfare gains arising from worldwide liberalization of the agricultural sector can be attributed to EU reforms of the Common Agricultural Policy (CAP) and that more than half of the entire effects of EU trade liberalization accrue to the reforms in the EU agricultural sector (HARRISON, RUTHERFORD and TARR 1996). Corresponding effects of liberalizing the US agricultural sector are much lower. Recent studies by the OECD Secretariat suggest declining levels of producer support and protection in the EU and the US relative to the benchmark years 1986-1988 (OECD 2001, p. 14). Yet, it is also noted that this has primarily been due to international price and exchange rate movements rather than agricultural policy changes.

The unbroken political attitude toward subsidization of the agricultural sector, the rising importance of so-called non-trade concerns in agriculture like food security, health, environmental protection, social stability in rural areas and animal protection as new cases for subsidization, and, finally, the still unsettled fundamentally different views in the EU and the USA on the use of biotechnological innovations in agricultural production are powerful barriers against liberalizing transatlantic trade in agriculture. It is therefore very unlikely that both partners would agree to treat agriculture in TAFTA in the same way as manufactures and to submit it to the "substantially-all-trade" criterion. What has failed in WTO dispute settlement procedures between the EU and the US cannot be easily solved within TAFTA.

The agricultural sector is the most important stumbling bloc in a TAFTA which would meet the "substantially-all-trade" criterion. Yet, it is not the only one. Other sensitive sectors which have been partly subject to bilateral disputes in the GATT/WTO in the past comprise steel, textiles, services, aviation, the defence industry and e-commerce.

Reproduced with permission of the copyright owner. Further reproduction prohibited without permission. 
More details on controversial issues can be collected from the list of barriers compiled by the US Trade Representative about the EU trade barriers and by the EU Commission about US barriers. ${ }^{5}$

In March 2002, the US decided to introduce protective tariffs for at least three years for steel and steel products. The tariffs of between 15 and 30 percent affect all imports except for the NAFTA partner countries Mexico and Canada and from countries under a special status, i.e. Russia, Turkey, Brazil and Argentina. The US tariffs will directly affect about half of EU steel exports to the US and thus provoke a new dispute settlement case under WTO rules.

\subsection{The External Dimension of TAFTA}

The overall economic effects of transatlantic liberalization can be examined by applying computable general equilibrium models. This has been done by BALDWIN and FRANCOIs $(1996,1997)$, who compare various degrees of transatlantic and multilateral liberalization schemes. Three simulations examine the effects of transatlantic liberalization for the involved partners and the rest of the world, whereas two further simulations analyze the consequences of multilateral efforts. The contents of these five simulation experiments are given in Table 4.

5 The National Trade Estimate Report on Foreign Trade Barriers by the US Trade Representative (USTR 2001) charges the EU with protectionist trade barriers or behavior in the following areas:

- The regime for the importation, sale, and distribution of bananas.

- The regime for the importation of meat products from hormone treated cattle.

- The market access for pharmaceuticals.

- The approval process for genetically modified products.

- Intellectual property protection.

- Measures affecting the grant of copyrights.

- The protection of trademarks and geographical indications for agricultural products and foodstuffs.

- The requirements for hush kitted and recertified aircrafts.

- Government procurement that discriminates against non-EU bids.

- Export subsidies and government support for Airbus and Airbus suppliers.

- The EU television broadcast requirement favoring European origin programs.

On the other side, the EU Commission (2002) complains about a number of US trade impediments, like:

- Excessive registration, documentation and invoice requirements for importers by the US customs authorities.

- Establishment of excessive user fees for formerly free service on the arrival of merchandise, vessels etc.

- "Buy-American" requirements of government procurement.

- Import restrictions or requirements concerning tuna-fishing, shrimps and dairy products.

- Government support for aircraft production and shipbuilding.

- Export subsidies for agricultural and fisheries product.

- Tax codes that discriminate against foreign companies. 
Table 4: Simulations of Transatlantic and Multilateral Liberalization and their Contents

\begin{tabular}{|c|c|}
\hline Simulation & Contents \\
\hline $\begin{array}{l}\text { Simulation } 1 \\
\text { Limited preferential } \\
\text { agreement }\end{array}$ & Elimination of industrial tariffs between TAFTA partners \\
\hline $\begin{array}{l}\text { Simulation } 2 \\
\text { Extended preferential } \\
\text { agreement }\end{array}$ & $\begin{array}{l}\text { Elimination of industrial tariffs between TAFTA partners } \\
\text { Elimination of agricultural protection between TAFTA partners } \\
\text { Elimination of remaining non tariffs barriers between TAFTA } \\
\text { partners }\end{array}$ \\
\hline
\end{tabular}

Simulation 3

Transatlantic Economic Elimination of industrial tariffs between TAFTA partners Space

Elimination of agricultural protection between TAFTA partners

Elimination of remaining non-tariffs-barriers between TAFTA partners

Standards harmonization, leading to a $10 \%$ reduction in the level of trading costs for TAFTA partners

Deepening of Procurement Agreement, to cover $50 \%$ of procurement

Simulation 4 OECD-wide multilateral liberalization

$50 \%$ reduction in industrial protection on a mosi-favorednation basis by $O E C D$

$50 \%$ reduction in agricultural protection on a most-favorednation basis by $O E C D$

further $20 \%$ reduction in agricultural production support by OECD

Standards harmonization, leading to a $10 \%$ reduction in level of trading costs for TAFTA partners

Deepening of Procurement Agreement, to cover $50 \%$ of procurement

Simulation 5

World-wide liberalization like simulation 4 , but with whole world undertaking mostfavored-nation liberalization of $50 \%$

Sources: BALDWIN and FRANCOIS $(1996,1997)$.

The BALDWIN and FRANCOIS approach uses the GTAP database and features 23 sectors and 10 regions. It is important to note that transatlantic liberalization measures include not only the EU and the US, but also corresponding steps by the two additional NAFTA members Mexico and Canada. The simulation results can be condensed into two main conclusions (cf. Table 5):

1. Negative effects from transatlantic liberalization for third countries do exist, but they are small. 
2. Multilateral liberalization efforts entail far more income gains than transatlantic schemes for the TAFTA partners (by factor 10) and substantial positive effects for the rest of the world.

The insights of these simulation exercises underline the superiority of a multilateral approach: If economic gains are the target of liberalization initiatives of the transatlantic partners, the approach should be multilateral, not bilateral.

Table 5: Income Effects From Transatlantic Liberalization ${ }^{\mathrm{a}}$

\begin{tabular}{|c|c|c|c|c|c|c|}
\hline & \multicolumn{2}{|c|}{ EU-15 } & \multicolumn{2}{|c|}{ NAFTA } & \multicolumn{2}{|c|}{ Rest of the World } \\
\hline & $\begin{array}{l}\text { Change of } \\
\text { GDP in } \\
\text { billions of } \\
\text { US dollar }\end{array}$ & $\begin{array}{l}\text { In } \\
\text { percent } \\
\text { of GDP }\end{array}$ & $\begin{array}{c}\text { Change of } \\
\text { GDP in } \\
\text { billions of } \\
\text { us dollar }\end{array}$ & $\begin{array}{c}\text { In } \\
\text { percent } \\
\text { of GDP }\end{array}$ & $\begin{array}{l}\text { Change of } \\
\text { GDP in } \\
\text { billions of } \\
\text { US dollar }\end{array}$ & $\begin{array}{c}\text { In } \\
\text { percent } \\
\text { of GDP }\end{array}$ \\
\hline $\begin{array}{l}\text { 1. Limited } \\
\text { preferential } \\
\text { agreement }\end{array}$ & 1.9 & 0.0 & 5.4 & 0.1 & -1.1 & -0.0 \\
\hline $\begin{array}{l}\text { 2. Extended } \\
\text { preferential } \\
\text { agreement }\end{array}$ & 16.9 & 0.3 & 17.8 & 0.3 & 0.4 & 0.0 \\
\hline $\begin{array}{l}\text { 3. Economic } \\
\text { space }\end{array}$ & 19.1 & 0.3 & 19.8 & 0.3 & -5.3 & -0.1 \\
\hline $\begin{array}{l}\text { 4. OECD-wide } \\
\text { liberalization }\end{array}$ & 222.1 & 3.3 & 93.4 & 1.5 & 144.4 & 1.9 \\
\hline $\begin{array}{l}\text { 5. World-wide } \\
\text { liberalization }\end{array}$ & 221.7 & 3.3 & 90.1 & 1.5 & 368.3 & 4.8 \\
\hline
\end{tabular}

\footnotetext{
a Based on simulations in computable general equilibrium models.

b Sum or weighted average of the eight other regions of the model.

c In 1992 US Dollar.
}

Sources: BALDWIN and FRANCOIS $(1996,1997)$; own calculations.

\section{Discrimination of third countries}

The discrimination issue is of critical importance when assessing the compliance of TAFTA with the WTO requirements. As discussed above, preferential tariff margins matter less since they are going to be eroded with ongoing multilateral tariff dismantling. Instead, for non-TAFTA countries, the non-application of MFN principles regarding the compliance with TAFTA rules, norms and regulations deserves more attention. TAFTA would probably set common rules for many trade-related policy areas, including the rights of establishment of companies, capital mobility, environmental standards, and perhaps even for competition policies and 
investment codes. Given TAFTA's economic weight and scale economies of rules, TAFTA rules would become globally dominant and binding ${ }^{6}$. How such rules would be developed, either by ex ante harmonization or by mutual recognition (ex post harmonization), would be essential for third countries. The latter procedure would give them options to either comply with the EU or the US rules as each of them would give them access to the entire TAFTA market. The former procedure, however, could deteriorate conditions of access to one of the two individual markets if the common standard would either be identical with the former US or EU standard or, more realistically, an average of the two. Net changes in access conditions would be ambiguous depending on changes in conditions of access to the other market. Again, the EU Single Market completion provides showcases for this problem. In principle, the EU Treaty offers both options but in practice has given priority to ex ante harmonization. As a result, regulations concerning the environment, for instance, became very much stricter in lower-income member states relative to pre-1992 and made access to these markets more costly for non-member states.

In collective bargaining, non-TAFTA countries could therefore understand TAFTA as a signal that the world's richest countries are more concerned in jointly discriminating against the rest of the world than in opening their markets to countries with less demanding regulations and standards. There is the danger that TAFTA would be seen as a only slightly modified form of the rich man's club which for a long time was a label for the GATT.

\section{Free trade arrangements with third countries}

The EU operates a most complex and extensive system of preferential trading agreement with other countries. It spans the entire spectrum of preferential trade agreements from free trade areas via customs unions, non-reciprocal agreements to unilateral trade concessions for developing countries (Generalised System of Preferences). The year 2000 Trade Policy Review Report of the WTO on the EU notes that exclusively MFN treatment applies only to imports from eight WTO members (WTO 2000, p. 29). One of them is the US so that the group of WTO members subject to MFN treatment would shrink further. Similarly, the US has free trade agreements with Canada and Mexico apart from "hub-and-spoke" agreements with few other countries.

6 An analogy of this issue can be found in the completion of the European Single Market in 1992. Negative effects for companies from neighbouring EFTA countries were basically found in excluding them from the application of EU-wide regulations which were relevant for companies. 
Under these conditions, TAFTA would have to handle not only the policy framework for direct current account transactions but take into account incentives for indirect "circumvention" trade which is also called trade deflection. Trade deflection occurs if external tariffs of FTA partners differ from each other to the extent that imports into the FTA country with the lowest external tariff before shipment to the destination country with a higher external tariff are profitable. For instance, TAFTA would have to fix conditions for Canadian exports to the EU which as a direct trade flow would not be eligible for duty-free treatment but could indirectly benefit from TAFTA via exports to the US under the Canadian-US Free Trade Agreement before being shipped to the EU. To discourage trade deflection, TAFTA needs a complex rule of origin procedure to guarantee that intra-TAFTA trade is treated more favourable than trade between a TAFTA member country with its "hub-and-spoke" partner country. With increasing globalisation of production and markets, this could fuel trade policy disputes and lead to high transaction costs in order to separate beneficiaries from non-beneficiaries. In contrast to a customs union with a common external tariff, rules of origin in a free trade area are much more susceptible to abuse for protectionist purposes (KRUEGER 1995).

\section{Consequences for the multilateral trading process}

Consequences for the multilateral trading process depend very much on the choice of the bilateral arrangement between the US and its spokes on the one hand and the EU and its spokes on the other hand. Either a Transatlantic Customs Union TACU or the automatic extension of all rights from bilateral agreements between one TAFTA member country and third parties to TAFTA in total (the TAFTA-South approach) could be instrumental to prevent a further policy-induced segmentation of markets. TACU would be more consistent with GATT Art. XXIV but would require a uniform level of protection against third countries in such highly disputed sectors like services and agriculture. Ideally, such level should approximate the lower one of the two national levels in order to comply with the prescription that third parties' rights under the WTO should not be nullified or impaired due to the formation of a customs union (BHAGWATI 1991, p. 77).

Nevertheless, the formation of TAFTA would constitute the strongest building bloc towards regionalism and thus the most serious challenge to the multilateral approach of trade liberalisation. Given the economic leverage of the two partners, third countries would have to accept the outcome of bilateral intra-TAFTA negotiations as binding for the rest of the 
world. Negotations under the WTO framework would become widely obsolete. Furthermore, given historical experiences of successful lobbying in both areas for special sectoral privileges, it is very likely that TAFTA would not cover all sectors. Hence, both sectoral incompleteness and regional limitation would bend WTO rules and undermine the multilateral process.

\section{Alternatives to TAFTA on the Multilateral Level}

Three alternatives to TAFTA are open to discussion:

\subsection{The Conventional Way: Subordination to the WTO}

The easiest way to strengthen the multilateral system is to support the start of a new multilateral liberalization round which was endorsed by WTO member states in November 2001 in Doha/Qatar. Clear signals of support would also be the postponement for all bilateral and regional agreements which are in the making, the speedy settlement of bilateral trade disputes, a strong engagement of the US President for receiving a negotiation mandate from Congress and the unconditional implementation of all commitments which were taken in the Uruguay Round including agriculture, services and textiles. By early 2002, however, there is little evidence that the conventional way to trade liberalization is the politically preferred one. Neither are bilateral or regional negotiations stalled nor are bilateral disputes settled. To the contrary, new serious conflicts as in steel trade seem to emerge. Finally, the implementation of Uruguay Round commitments is sluggish and characterized by trials to find loopholes in the legal documents.

\subsection{The Unconventional Way: Liberalization à la Carte}

When the authors addressed the issue of TAFTA for the first time (SIEBERT ET AL. 1996) they were fairly optimistic that a US-EU specific transatlantic liberalization initiative TALI could be based on the objective to act as a spear-head for the implementation for the Uruguay Round. Six years of experience with the implementation record, however, do not give rise to optimism. The two parties refused to accept this role and instead became victims of a quagmire of delays, disputes and mutual dissatisfaction. More modesty seems at stake. Such a minimum approach 
could comprise initiatives to so-called trade facilitation which includes, for instance, the streamlining of customs declaration procedures or the facilitation of preinspection procedures. Bilateral working groups could work out common proposals and open them to third parties within the multilateral trading order. The two parties could also set the pace for new issues which came up only after the Uruguay Round such as rules for trading in electronic media, a WTO-consistent application of the so-called precautionary principle as well as the identification of hitherto nontransparent trading costs. To concentrate aspects of trade facilitation on new issues instead of the old ones, carries an important advantage. The new issues are not yet blocked by vested interests, hence, they give the two parties a chance to act as forerunners.

\subsection{The Controversial Way: Moving Towards Open Regionalism}

For the time being, it seems unrealistic to expect a breakthrough in the so-called open regionalism of APEC which basically is a regionally concerted approach to conditional MFN. Heterogeneity and diverging interests are seemingly too large to be reconcilable even within a wide framework and a long time horizon until the year 2020. Instead, the concept of open regionalism seems to be more promising in the transatlantic arena where the principle of conditional MFN treatment can be more easily extended to the trading partners of the US and EU especially if these partners are already linked to one of the two areas through bilateral agreements. The underlying idea is to commit the countries to the principle of MFN treatment and to induce them by facilitating the access to the two transatlantic markets. As an example, the free trade agreement of the Americas would be more acceptable and appealing to Latin American countries if any concessions negotiated between the North and the Latin American countries would be offered to the EU provided that the EU would follow suit by opening its market. In doing so, EU-US trade cooperation could still be called a regional initiative like TALI but would loose its negative momentum as a "lock-out mechanism" against third countries.

Reproduced with permission of the copyright owner. Further reproduction prohibited without permission. 


\section{Conclusions}

By the beginning of the new century, both the US and the EU seem to pay lip services to the multilateral system while intensifying their bilateral negotiations with third countries. This approach is highly vulnerable to raising transaction costs for countries which are excluded from these negotiations. The idea of a Transatlantic Free Trade Area is open to similar concerns. In this paper, we have shown that the disadvantages of TAFTA to the multilateral system are substantial and that much more flexible and open approaches to transatlantic trade liberalization promise better results both for the partners as well as the rest of the world. Regrettably, however, neither the EU nor the US seem prepared to act jointly as pace setters for the liberalization of either old or new issues. In this respect, the old regionalism still seems to be unbeaten. TAFTA with its inherent lockout characteristics would be a further step towards closed regionalism. Instead, there is more to be gained in terms of world welfare if the approach of conditional MFN treatment which seem to have failed in the Asia-Pacific Rim because of excessive heterogeneity would be taken more seriously in the North Atlantic Rim. This approval would place the US and the EU jointly in the driver's seat of a multilateral liberalization convoi. 


\section{References}

Baldwin, Richard E. and Joseph Francois (1996): Transatlantic Free

Trade: A Quantitative Assessment, mimeo

Baldwin, Richard E. and Joseph Francois (1997): Preferential Trade

Liberalization in the North Atlantic, Discussion Paper No. 1611, CEPR

- Centre for Economic Policy Research, London

Bhagwat, JAGDish (1991): The World Trading System at Risk. New York:

Harvester Wheatsheaf

Bhagwati, Jagdish, Elias Dinopoulos and Karyin Wong (1992): Quid

Pro Ouo Foreign Investment, American Economic Review, Vol. 82, No.

2, p. 186-190

DER HANDEL (2001): Interview “Transatlantische Währung möglich”.

1.11.2001, Frankfurt am Main

DOME (Database on Mergers in Europe) (2002): available under: http:// www.uni-kiel.de/ifw/forschung/fo1.htm

Donges, Juergen B., Andreas Freytag and Ralf Zimmermann (1997): TAFTA: Assuring Its Compatibility with Global Free Trade. The World Economy, Vol. 20 No. 5, p. 567-583

ETHIER, Wilfred (1998): The New Regionalism. The Economic Journal, Vol. 108, July, p. 1149-1161

European Commission (2002): Market Access Sectoral and Trade Barriers Database: United States - General Features of Trade Policy. Brussels. Available under: http://mkaccdb.eu.int/mkdb/mkdb.pl

Eurostat (2001): European Union Foreign Direct Investment Yearbook 2000, Luxemburg

Finger, J. Michael, Merlinda D. IngCo and Ulrich Reincke (1996): The Uruguay Round. Statistics on Tariff Concessions Given and Received, World Bank, Washington D.C.

Hammermann, Felix and Jörn KLeInert (2001): Die DOME-Fusionsdatenbank. Die Weltwirtschaft, No. 4, p. 405-414

Harrison, GlenN W., Thomas F. Rutherford and David Tarr (1996): Quantifying the Uruguay Round; in: WILL, MARTIN and L. AlAN WINTERS (Eds.), The Uruguay Round and the Developing Countries, Cambridge: CUP, p. 216-252

Hertel, Thomas, Terrie Walmsley and Ken Hakura (2001): Dynamic Effects at the "New Age" Free Trade Agreement between Japan and Singapore. Journal of Economic Integration, Vol. 16, No. 4, p. 446-484

HindLEY, BRIAN (1999): New Institutions for Transatlantic Trade? In:

International Affairs, Vol. 75, p. 45-60 
Krueger, Anne O. (1995): Free Trade Agreements Versus Customs Unions. National Bureau of Economic Research Working Paper 5084, Cambridge, MA

LANGHAMMER, ROLF J. (1999): Regional Integration APEC Style: Lessons from Regional Integration EU Style. ASEAN Economic Bulletin, Vol. 16, No. 1, p. 1-17

LANGHAMMER, ROLF J. and Ludger WÖBMANN (2002): Erscheinungsformen regionaler Integrationsabkommen im weltwirtschaftlichen Ordnungsrahmen: Defizite und Dynamik. Forthcoming in Conference Proceedings of the Forschungsseminar Radein e.V., Schriften zu Ordnungsfragen der Wirtschaft

LÜbcke, Britta and Daniel Piazolo (1998): Die dynamischen Auswirkungen einer Nordatlantischen Wirtschaftsgemeinschaft (NATEC). Homo Oeconomicus, Vol. 15, No. 2, p. 195-216

OECD (2001): Agricultural Policies in OECD Countries. Monitoring and Evaluation 2001. Highlights, Paris: OECD.

SCHOTT, JEFFREY J. (1995): Reflections on TAFTA. Mimeo, Institute for International Economics, Washington, D.C., September 1995

Schott, JEFFrey J. and BARBARA OEgG (2001): Europe and the Americas: Toward a TAFTA-South? The World Economy, Vol. 24, No. 6, p. $745-755$

SIEBERT, HORST (2002): The World Economy, London: Routledge, $2^{\text {nd }}$ edition Siebert, Horst, Rolf J. Langhammer and Daniel Piazolo (1996): The Transatlantic Free Trade Area. Fuelling Trade Discrimination or Global Liberalization? Journal of World Trade, Vol. 30, No. 3, p. 45-61

United Nations: Monthly Bulletin of Statistics. New York, various issues

United States Trade Representative (2001): 2001 National Trade Estimate Report on Foreign Trade Barriers. Washington, D.C. Available under: http://www.ustr.gov/html/2001_contents.html

United States Trade Representative (USTR) (1994): 1994 National Trade Estimate Report on Foreign Trade Barriers. Washington. D.C.

US Department of Commerce: Survey of Current Business. Washington, D.C., various issues

WOLFE, ROBERT (1996): Vers l'ALETA? Le Libre-Echange Transatlantique et la Politique Etrangere Canadienne; in: Etudes internationales, Institut Quebecois des Hautes Etudes Internationales, Université Laval, Vol. 27, No. 2, p. 353-380

WTO (2001): Market Access: Unfinished Business. Post-Uruguay Round Inventory and Issues, Special Studies, Vol. 6, Geneva, April

WTO (2000): Trade Policy Review, European Union, Vol. 1, Geneva, November 
Reproduced with permission of the copyright owner. Further reproduction prohibited without permission. 